\title{
The Problem of Islamic Religious Education Learning Against Muslim Minority Students
}

\author{
M. Iqbal Huda ${ }^{1}$, Abdul Fattah,* \\ 1,2 Universitas Islam Negeri Maulana Malik Ibrahim Malang, Indonesia \\ *Corresponding author.Email: abdul.fattah@pai.uin-malang.ac.id
}

\begin{abstract}
The problem of Islamic education learning in every school is undoubtedly different. The location of the school also influences the problem. The problems that occur in schools in the Muslim minority areas will be undoubtedly different from the issues that occur in schools in the Muslim majority areas. In Muslim minority areas, Islamic education's learning process is the biggest and most challenging challenge for Teachers. Therefore, the Teacher must have efforts to overcome these learning problems to create an effective learning process. This research aims to determine the learning process of Islamic education. The issues of Islamic education learning and efforts to resolve the problems of Islamic education learning. This research uses a qualitative approach, and it is a descriptive qualitative type. This research's informants are the head-master, Islamic education teacher, and students of Junior High School Dharma Praja. This research's results are the learning process of Islamic education in Junior High School Dharma Praja is still not going well. The problems of Islamic education learning in this school are student motivation is low, many students cannot recite and write Al-Qur'an well, and the high cost of an Islamic school. The problems faced by Islamic education teachers are the unavailability of room for Islamic education learning and the lack of Islamic education teachers in school. The efforts to resolve Islamic education learning problems in this school are by creating a comfortable, conducive, and creative learning atmosphere and Islamic education teacher makes additional study to improve reciting Al-Qur'an.
\end{abstract}

Keywords: Problems Learning, Islamic Education, Muslim Minority.

\section{INTRODUCTION}

The legal protection of the human rights of minority groups in Indonesia has been governed by ICCPR (International Covenant on Civil and Political Rights), displayed in the article 27 "In those States in which ethnic, religious or linguistic minorities exist, persons belonging to such minorities shall not be denied the right, in community with the other members of their group, to enjoy their own culture, to profess and practice their religion, or to use their language.." [1].

The scope of an existing minority in a State can be based on ethnicity, religion, belief, and minorities in the language sphere. Of these three scopes, the State has an obligation to ensure that these rights' existence and exercise are protected from infringement. Therefore, all of this requires positive protection measures from the actions of the State itself, can be through the authority of the legislative, judicial or administrative, and the actions of others or communities within the territory of the State concerned [2].

For people who are in Muslim minority areas, it is not easy to survive in the midst of the siege of people who are not as religious as us. It takes a strong mental and motivational high self-adjustment in order to remain in one community. The same is the case with Islamic education in muslim minority areas. Ofcourse there are many twists and turns of travel and struggle to go through. This is what makes the discussion in this paper more interesting. If we look closely at the geographical location and distribution of Muslims around the world, then the latest statistical data shows approximately 1.7 billion Muslims, a considerable custodia data. Moreover, lately the development of Muslims, especially in Europe, is increasing in quantity. This certainly has an impact on the cultural clash between East and West, making it interesting to explore further [3]. 
The research conducted in the United States suggests that Muslim students find it very difficult to carry out their religious obligations during lectures, so they have to choose between attending lectures and praying. In addition to the problem of time, places of worship are also an obstacle when carrying out worship, especially for a Muslim woman who cannot worship comfortably and is even afraid to worship in public places, so they have to worship in a makeshift place. However, because Islam is easy religion, worship can still be carried out even with limited time and space [4].

Muslims living in Muslim minority areas should interact and maintain proper treatment and keep conflict with the local non-Muslim community. But the attitude must be able to distinguish positioning and adjusting to akidah. As these rules have been described in minority jurist; In addition, it is expected to maintain a local cultural identity while maintaining Islamic teachings and values. Muslim minority Community can wisely convey his wishes or aspirations so as not to cause conflict. The government is also expected to treat Muslim minority groups fairly and propositionally [5]. There are also interesting lessons to learn for multicultural societies coming to terms with Muslim minorities, and other Muslims working to develope in a non-Muslim environment. Although these groups are relatively small and have a low profile in the Muslim world, they are also deeply rooted, having been resident in their areas for significantly longer than the modern states that now surround them [6].

In dealing with the problems that occur in Islamic religious learning in Muslim minority schools, it is necessary to process both teachers, students, and principals who can be expected to help solve existing problems. Many Muslims see Islamic schools as an option not only to provide up-to-date educational opportunities in line with their perceptions of Muslim identity, but also to denote an agenda of resistance to challenge existing racism and power relations [7].

As for efforts to solve the problem that occurs in the Islamic learning process in schools, several approaches can be used both at the primary and Junior High School, can be reviewed from several aspects including the Islamic religious education learning process will run smoothly so that the objectives in the learning of Islamic religious education and the atmosphere of Islamic religious learning can be achieved to the maximum. There needs to be a solution to solving the problems that occur in the learning process of Islamic religious education.

A. Majid [8] explaining the need for a faith approach, which is to give students the opportunity to develop an understanding of God as the source of life of beings in this realm. Also, the experience approach also needs to be applied by giving students the opportunity to practice and feel the results of the experience of worship and morality in the face of tasks and problems in life. Then the habitual approach by giving students the opportunity to get used to attitudes and behaviors that conform to the teachings of Islam and the culture of the nation in the face of life problems.

In addition, A. Majid [8] also states the rational approach by giving students a role in understanding and distinguishing teaching materials in material standards and related to good behavior in life as well as an emotional approach by uploading students' feelings in living behaviors that conform to the teachings of the nation's religion and culture. The functional approach should also be presented with the form of all material standards (Qur'an, faith, morality, fiqh, date) in terms of its benefits for learners in daily life. As well as an exemplary approach, namely making the fiitur of religious and non-religious teachers and all school parties as a mirror of human personality.

Teachers, as we know that teachers have a strategic position in developing all the potential that students have. While there are learning activities, education is needed because, in educators, there will be success and salvation of the future of the nation. This is because educators have an obligation to form a prosperous person born and inner, be it through the study of Islamic religious education and public education.

Educators should be able to become professional educators, oriented to students in full creativity and daily activities in Islamic religious education learning. Pupuh Faturrahman in Khadija [9] argues that there are minimal strategies that can be developed in an effort to create/ build effective communication between teachers and learners, among others is respect, empathy, audible, clear meaning, and humility.

The above teachers' role may work well if the teachers on one side and the students on the other side support each other and complement each other. There are several things in improving the role of teachers, namely: Strengthening and improving teacher competency. In accordance with Law No. 14 of 2005. The Law of Teachers and Lecturers explains that teachers have academic quality, competence, and certificate of educators, are physically and spiritually healthy, and have the ability to realize national educational goals [10].

Also, in the world of Islamic religious education, students are one of the most essential factors therefore, everything related to individual students, educators must be responsive and try to find solutions. This is because students are always developing, where this development is slightly influenced by the level of intelligence of each student. The efforts taken by Islamic religious education in addressing the problem are by providing learning motivation to the students as follows; First, give me a homework assignment. Second, Form a study group. 
Third, Add hours of lessons. Fourth, Holding a Fifth competition or competition, advising on the importance of learning, especially in globalization.

The student of Junior High School which is Aggressive; this indicates a potential position to develop. As for some strategic issues that can be used as references for school program plans, such as: 1) To involve Parents, Lecturers or science experts; 2) Science Laboratory Assistant recruitment; 3) Procurement and Maintenance of Science Laboratory Facilities; 4) Human Resource Development; and 5) To be Active in science competitions/ Olympiads [11].

\section{METHOD}

This research uses a qualitative approach. Qualitative research is a research method based on the philosophy of postpositivism, used to examine natural objects. Researchers are positioned as crucial instruments. This data collection technique is done triangulate (combined); the data analysis is inductive, as well as the results of research from qualitative methods emphasize more on meaning than generalization [12].

In accordance with this research, the study examines the facts related to the problems in the learning process of Islamic religious education at Junior High School Dharma Praja; efforts to study what is done in solving the problem of Islamic religious education in Junior High School Dharma Praja.

\section{RESULT AND DISCUSSION}

\subsection{Islamic Religious Education Learning Process}

To know the process of implementing Islamic Education learning at Junior High School Dharma Praja can be seen from opening, presenting, and closing the learning. From the researchers' findings, the opening done by religious teachers is by saying greetings and ensuring students' readiness to learn by having to open each student's textbook.

In implementing presenting learning materials done by teachers by having students read books briefly, teachers explain learning materials by using the method of lectures, frequently asked questions, and discussion. The Teacher's explanation is only done in front of the class that only a few students can understand the explanation.

From the researchers' findings, it can be known that the cover done by religious teachers is to give assignments to students in an unrelenting way, to ensure the presence of students, and then say greetings before leaving the classroom.

\subsection{The Problems of Learning Islamic Religious Education}

While problematic Islamic religious education learning is found in several components, among others problems that occur in students and problems that occur in educators / teachers.

Following the data exposure of the study results of the authors described in the previous chapter, there are five problems of students in Islamic religious education learning in Junior High School Dharma Praja namely: Lack of interest to follow religious lessons because religious lessons do not enter regular hours and teachers set their hours and days to conduct the learning process. So students themselves become lazy to enter religious lesson hours. Students tend not to enter the classroom and prefer to go to the cafeteria as if entering the classroom. Students like to talk to themselves with their friends, play mobile phones, and ignore teachers' explanations.

Still can't read the writing of the Qur'an because students have no special lessons or hours about reading the Qur'an in school. Many of the students are new to Iqra' because students can only study independently outside of school, whether it is at home with parents or in mosques or elsewhere that have learning to read the Qur'an.

The school environment also influences students to participate because most Muslims are few so that students get along more with Hindu students because in hindu-majority schools more. What's more, the middle school days were not able to get away with social relationships.

The basic factor is that Muslim children want to go to other schools that are predominantly Hindu because Islamic-based schools are more expensive than public schools. Therefore, parents prefer to put their children in public school with less intense religious lessons against the backdrop of cheaper entry.

Teachers are certainly the most essential factor in a learning process because here, the Teacher's job is to convey the material to the learner to know or understand what the teacher wants to teach. The Teacher at Junior High School Dharma Praja, according to the statement from the students of his religious Teacher is rarely present in the class of his students only told in the library to read and then just absent.

While the problem of learning from the Teacher element is the lack of Islamic teachers in Denpasar area is complained by the existing religious teachers because there is only one in each school and the Teacher can teach more than two schools. They are thus causing the existing teachers not to teach due to the number of teaching hours of more than one school. According to 
Islamic teachers' statement because there are also still many religious teachers who have not graduated.

The absence of space for religious learning is also complained about by teachers because the place that often moves around there is no special room for religious learning itself. Sometimes it is done in science labs, libraries, and city parks near schools. It also affects the model and method of learning teachers must be precise and in accordance with the place used by learning.

The lack of interest in Islamic subjects makes teachers also just convey the material in the student worksheet regardless of whether they can understand and understand it in daily life. Because of the hours of religious lessons that are outside of regular hours.

The Teacher complained about the prayer time because the school entered during the day at 12.30 central Indonesia time to coincide with the dzuhur prayer. The teacher could not directly monitor his students to perform dzuhur prayer the Ashar prayer time at 15:30 central Indonesia time.

\subsection{The Efforts in overcoming the Problems of Learning Islamic Religious Education}

In the face of the problem, Junior High School Dharma Praja uses various efforts by creating a comfortable and innovative classroom atmosphere so that students are interested in attending high religious lessons and rewarding with additional value.

This is also as moh Uzer Usman said [13] in his book titled Becoming a Professional Teacher, the Teacher's job is to awaken the motivation of the child so that he wants to do his learning. Motivation can arise from within the individual and can also arise due to outside influences.

The findings of the study obtained from Junior High School Dharma Praja are the lack of ability to read and write the Qur'an. Teachers have been trying to conduct reading lessons in the Qur'an outside of religious studies at school. A predominantly Hindu neighborhood.

In addition, the non-Muslim environment also affects the spirit of student learning, while the Teacher only justifies and only reminds students of the limitations of religion. Because the majority of Hindus are not Muslims.

The cost of Islamic-based schools that make parents willing their children to go to public schools, so that the ability of Islamic students is also low.

The lack of Islamic teachers in public schools is also an obstacle to improving the quality of Islamic education. In this case the principal has explained that only one Teacher who teaches religious because of the small number of students and in addition religious subjects are outside regular hours and regulated by their religious teachers themselves. So that's what makes the head feel enough with the number of religious teachers who are only one in school.

This is as Khadija [9] said in her book, Teachers as we know that teachers have a strategic position in the development of all the potential that students have. While there are learning activities, that is where education is needed because, in educators, there will be success and salvation of the future of the nation. This is because educators have an obligation to form a prosperous person born and inner, be it through the study of Islamic religious education and public education.

In addition, the absence of room for Islamic religious learning is also a decrease in students' spirit in studying Islamic religious education. In this case it is also still in the stage of a plan to create a kind of hall for worship so that students can carry out their worship according to their own beliefs comfortably. However, this is still the plan stage and cannot be in the near term due to cost factors.

Also, the lack of interest in Islamic subjects is also a decrease in students' interest in studying Islamic Religious Education; in this case, teachers also try to create a comfortable and innovative classroom atmosphere by using learning methods and models that suit students so that students' interest in religious subjects is high and make students more aware that religious lessons are very important especially in an environment where the majority are not Muslims.

This is also as moh Uzer Usman said [13] in his book titled Becoming a Professional Teacher, the Teacher's job is to awaken the motivation of the child so that he wants to do his learning. Motivation can arise from within the individual and can also arise due to outside influences.

\section{CONCLUSION}

Based on the results of previous research and discussion, researchers can conclude that the problem obtained by the researcher before conducting further research in Islamic religious education in Junior High School Dharma Praja school is the Teacher who is lacking in mastering the classroom and the absence of adequate facilities in the religious learning process and moreover there is only one religious Teacher, students who do not respect the Teacher, the atmosphere is not conducive of some students who play mobile phones and chat with close friends when the Teacher explains the lesson. As well as external concerns about the more expensive Islamic-based schools than public schools in denpasar area. 
Based on the theory taken by researchers should be Guru is one of the elements of educators who must have the ability to understand how youngness has by students and the ability to organize the learning process so that it becomes more targeted. And infrastructure facilities are also quite important elements because the infrastructure facilities also support teachers' success in controlling the atmosphere in the class.

Researchers do get results from this study. Researchers conduct qualitative research methods with phenomenological approaches that will provide more indepth products about the problems obtained by both teachers and students.

The problem for students is lack of interest in following Islamic lessons. There are still many students who have not been able to read the Qur'an. The school environment is predominantly Hindu. More expensive Islamic schools and teachers are rarely present in class.

While the problem in educators, namely: Lack of Islamic teachers; There is no room for Islamic learning and a lack of interest in Islamic subjects.

Efforts to problem students are to create a comfortable, innovative, conducive learning environment and increase student motivation by advising students to be more passionate about learning and rewarding students with value and praise for their success in education. Hold additional special lessons to read the Quran outside of school hours. There is no solution because, in the school environment, the students are predominantly Hindu. Islamic-based schools are more expensive than in existing public schools. Teachers reasoned the hectic teaching hours reached other schools.

\section{AUTHORS' CONTRIBUTIONS}

This research has a contribution for the current conditions, where the concept of this study follows the current state of conducting research related to The Problem of Islamic Religious Education Learning Against Muslim Minority Students. Data collection showed using interview techniques and documentation so that the collected data is more accurate. Data analysis carefully, so that accurate results are obtainable. The standard preparation prepares articles for research articles.

\section{ACKNOWLEDGMENT}

The author would like to acknowledge the Rector, Dean and all of parties of Universitas Islam Negeri Maulana Malik Ibrahim Malang and Junior High School Dharma Praja Bali in supporting the publication of this article.

\section{REFERENCES}

[1] "OHCHR | International Covenant on Civil and Political Rights.” https://www.ohchr.org/en/professionalinterest/page s/ccpr.aspx (accessed Oct. 22, 2020).

[2] Y. Z. Fadhli, "Kedudukan Kelompok Minoritas dalam Perspektif HAM dan Perlindungan Hukumnya Di Indonesia," Jurnal Konstitusi, vol. 11, p. 19, 2014, doi: https://doi.org/10.31078/jk\%25x.

[3] D. S. Napitupulu and S. Fahmi, "Pendidikan Islam Muslim Minoritas (Kasus di Eropa Barat)," Belajea; Jurnal Pendidikan Islam, vol. 5, no. 1, Art. no. 1, May 2020, doi: 10.29240/belajea.v5i1.938.

[4] D. L. Anderson, "Muslim International Students in the United States:," Journal of International Students, vol. 10, no. 2, Art. no. 2, May 2020, doi: 10.32674/jis.v10i2.965.

[5] A. Wahib, "PERGULATAN PENDIDIKAN AGAMA ISLAM DI KAWASAN MINORITAS MUSLIM," Walisongo: Jurnal Penelitian Sosial Keagamaan, vol. 19, no. 2, Art. no. 2, Dec. 2011, doi: https://doi.org/10.21580/ws.19.2.169.

[6] J. Goodman, "A Different Path: The Minority Muslim Experience in Southeast Asia," Doctor of Philosophy, University of Exeter, United Kingdom, 2020.

[7] S. Shah, "Muslim schools in secular societies: persistence or resistance!," British Journal of Religious Education, vol. 34, no. 1, pp. 51-65, Jan. 2012, doi: 10.1080/01416200.2011.601897.

[8] A. Majid, Pendidikan agama Islam berbasis kompetensi: konsep dan implementasi kurikulum 2004. Remaja Rosdakarya, 2004.

[9] K. Khadijah, Belajar Dan Pembelajaran. Bandung: Citapustaka Media, 2013.

[10] Undang-Undang Republik Indonesia Nomor 14 Tahun 2005 Tentang Guru dan Dosen, vol. 14. 2005.

[11] F. Y. Hartini, A. Istiqlal, and T. C. Kurniatun, "Strategic Plan in Improving Students' Science Competency," Mar. 2019, pp. 197-201, doi: 10.2991/icream-18.2019.40.

[12] S. Sugiyono, Metode Penelitian Pendidikan: (Pendekatan Kuantitatif, Kualitatif dan $R \& D$ ). Bandung: Alfabeta, 2017.

[13] M. U. Usman, Menjadi Guru Profesional. Bandung: Remaja Rosdakarya, 1999. 